\title{
The Social Media-Based Approach in Teaching Writing at Jember University, Indonesia
}

\author{
Hairus Salikin ${ }^{1} \&$ Saidna Zulfiqar Bin Tahir $^{2}$ \\ ${ }^{1}$ The Faculty of Humanities, Jember University, Indonesia \\ ${ }^{2}$ English Education Department, the University of Iqra Buru, Maluku, Indonesia \\ Correspondence: Saidna Zulfiqar Bin Tahir, English Education Department, the University of Iqra Buru, Ambon, \\ Maluku, Indonesia. E-mail: saidnazulfiqar@gmail.com
}

Received: January 2, 2017 Accepted: January 20, 2017 Online Published: February 9, 2017

doi:10.5539/ijel.v7n3p46 URL: http://dx.doi.org/10.5539/ijel.v7n3p46

\begin{abstract}
In the last of few years, the use of social media has become the main topic in teaching and learning, but by the rapid development of technology, there must be a shift of students' interest in employment the media. Thus, this research aimed to reveal; (1) Do the use of social media improve the EFL students' writing skill; and (2) What factors affect the EFL students' writing achievement. This research employed experimental design. The respondent of the current research were two classes of third semester EFL students at the University of Jember. In collecting data, the researchers used writing test, interview, and observation. The data were analyzed using SPSS 18.0. The researchers found that; 1) The use of social media did not significantly improve the students' writing skill, and 2) There were some specific factors that hindered the students; achievement in writing descriptive text.
\end{abstract}

Keywords: social media, English teaching, writing skill, descriptive text

\section{Introduction}

\subsection{Background}

The social media are computer-mediated tools that allow people to communicate, share ideas, exchange information, and share images/audio/video to the virtual world community through the internet. Social media is also a collective online communication channel dedicated to interact, share content, and collaboration-based society. It has become an integral part of people's lives as a social site and has changed the way people interact, live, work, and acquire knowledge and learning through the internet (Kaplan \& Michael, 2010, p. 61; Almeida, 2002; Kietzmann, 2011, pp. 241-251; Tang et al., 2012, pp. 41-75; Aichner \& Jacob, 2015, pp. 257-275; Bin Tahir, 2015, pp. 174-181).

Today, the number of internet users in Indonesia reached 73 million users of this year; it is equivalent to 29 percent of users who access the social media as the highest activity. More than half of internet users, or 58.4 percent were aged between 12 to 34 years old who get online for five hours a day using a laptop or personal computer; and approximately they get online for two hours via a mobile device (The Jakarta Post, 2015). The Indonesian internet users over the last four years can be seen in table 1 below.

Table 1. Indonesian internet users

\begin{tabular}{|c|c|c|c|c|c|c|c|c|}
\hline $\begin{array}{l}\text { Year } \\
\text { (July) }\end{array}$ & $\begin{array}{l}\text { Internet } \\
\text { Users }\end{array}$ & $\begin{array}{l}\text { User } \\
\text { Growth }\end{array}$ & New Users & $\begin{array}{l}\text { Country } \\
\text { Population }\end{array}$ & $\begin{array}{l}\text { Population } \\
\text { Change }\end{array}$ & $\begin{array}{l}(\% \text { of Pop. } \\
\text { with Internt })\end{array}$ & $\begin{array}{l}\text { Country's Share } \\
\text { of Internet Users }\end{array}$ & $\begin{array}{l}\text { Global } \\
\text { Rank }\end{array}$ \\
\hline 2014 & $42,258,82$ & $9 \%$ & $3,468,057$ & $252,812,245$ & $1.18 \%$ & $16.72 \%$ & $1.45 \%$ & 12 \\
\hline 2013 & $38,790,76$ & $2 \%$ & 872,427 & $249,865,631$ & $1.22 \%$ & $15.52 \%$ & $1.43 \%$ & 12 \\
\hline 2012 & $37,918,34$ & $27 \%$ & $7,979,498$ & $246,864,191$ & $1.26 \%$ & $15.36 \%$ & $1.51 \%$ & 12 \\
\hline 2011 & $29,938,84$ & $14 \%$ & $3,656,969$ & $243,801,639$ & $1.30 \%$ & $12.28 \%$ & $1.31 \%$ & 17 \\
\hline
\end{tabular}

Source: Internet Live Stats (www.InternetLiveStats.com), 2015.

The growth in the number of internet users in Indonesia reached 13 percent (per year) to 71.2 million users in 2013. It is based on data provided by the Association of Indonesian Internet (APJII). Overall, the internet penetration in 
Indonesia at the end of 2013 was about $28 \%$ of the total population of the country citizen. The Indonesian internet users are estimated at 107 million at the end of 2014 and 139 million by 2015 (based on the Millennium Development Goals). However, the sector will require the government support to achieve these numbers (APJII, 2015).

As the most popular of the social network used by internet users in Indonesia is Facebook, Twitter, and Google Plus as a social media that occupy in the top list. Interestingly, although Indonesia has become a major market for the Path, the report indicates that Instagram and Pinterest are still more popular than personal social networking. There are many chat applications fighting for supremacy in Indonesia, and according to the report, WhatsApp, Facebook, Messenger, Skype, and Line is still popular in Indonesia (Millward et al., 2015, pp. 31-49).

The data shows that the social media have enabled changes in the way of Indonesian citizens live, work interact and acquire knowledge and learning. The use of social media has shifted public service functions from manual to online such as government, health sector, and also in the field of education and training that can be powered by a teacher as a medium of language teaching and learning in the schools and universities, especially at the University of Jember, Indonesia.

So far, the majority of English Literature Department students of Jember University have already used the internet through a mobile phone, and some of them still use the laptop or computer $\mathrm{PC}$ to access the social media such Facebook, Twitter, Instagram, WhatsApp, Wechat, etc. However, the applications are often used by them are Facebook and Whatsapp to chat or comment on a friend's status privately and in groups that can be used to further improve their proficiency in English writing.

Based on the data of the final examination result of English students in Faculty of Humanities for the last of three years (2013-2015) on the subjects of writing shows that the mean score of students' achievement was in the average to the fairly good classification that can be seen in table 2 below:

Table 2. The students' writing achievement on final examination (UAS) of English literature department

\begin{tabular}{lllll}
\hline & & \multicolumn{3}{l}{ Mean Score } \\
\cline { 3 - 5 } No & Semester & 2013 & 2014 & 2015 \\
\hline 1 & $2^{\text {nd }}$ Semester & 71.34 & 72.07 & 70.12 \\
2 & $4^{\text {th }}$ Semester & 74.01 & 70.33 & 71.38 \\
3 & $6^{\text {th }}$ Semester & 72.03 & 73.05 & 70.08 \\
\hline
\end{tabular}

Source: Academic office of English Literature Department, 2015.

The data shows that the mean score of students' achievement in writing was in the average to fairly good classification and there was no significant improvement from academic years to years. This is due to the lecturers who teach writing using international standards of scientific writing which difficult for students to understand and write down their ideas in a paragraph. This situation should be overcome by the lecturers and the university to increase the students' achievement.

The lecturers should make efforts in teaching to make their class interesting by using various methods, techniques, instruments, and materials in order to stimulate the students to learn English. In writing subject, for example, the students are served with conductive learning activity so they can write in English as well as possible. The first thing a lecturer should do is to create the best condition for learning. The lecturer is responsible for creating a situation that provides opportunities and stimulates the students to communicate English. Consequently, it can develop the students' self-confidence and have quality in writing.

The use of social media somehow could improve the students' achievement in learning. It is in line with the result of some previous studies concern the use of internet and social media in language teaching and learning. The results show that the use of the internet and social media are effective to increase the students' achievement such in listening, speaking, writing and (Kaplan \& Michael, 2010, p. 61; Almeida, 2002; Kietzmann, 2011, pp. 241-251; Tang et al., 2012, pp. 41-75; Aichner \& Jacob, 2015, pp. 257-275; Bin Tahir, 2015, pp. 174-181). Those studies did not concern yet to study in an in-depth the implementation of social media for teaching and learning. Therefore, the researchers intend to conduct a research on "The social media-based approach in teaching writing" especially in empowering the common application of the social media use by the students that is Facebook and WhatsApp as media of teaching and learning writing at Jember University.

The result of this study is expected theoretically to enrich insights into Information and communication Technology (ICT) in language teaching and learning especially the use of social media in teaching and learning 
writing. Practically, this study will enable the English language lecturers to implement the appropriate social media and be creative to modification the application facilities which motivate and help the students to increase their writing skill.

\subsection{The Social Media}

The Social media is defined as a group of Internet-based applications that build on the ideological of Web 2.0 technologies and that allows the creation and exchanging of user-generated content. It is a computer-mediated tool that allows people to create, share, or exchange information, ideas, images, and videos in virtual communication and networking (Kaplan \& Michael, 2010, p. 61). Furthermore, social media depends on mobile and web-based technologies to create highly interactive platform through which individuals and communities sharing, create, discuss, and modify user-generated content. They introduced substantial changes into the communication between individuals, communities, organizations, and companies (Kietzmann, Jan, Kristopher, \& Hermkens, 2011, pp. 241-251). The changes in the way of communication are the focus of the techno self-study. So the social media is different from traditional or the industry media in many ways, including the quality, frequency, usability, proximity and permanent. Social media operates in the transmission system dialogical, (many sources to many recipients) (Pavlik, MacIntoch, John, \& Shawn, 2015, p. 189). This is in contrast to traditional media that operates under a monologic transmission model (one source to many receivers).

"Social media has been broadly defined to refer to the much relatively inexpensive and widely accessible electronic tools that enable anyone to publish and access information, collaborate on a common effort, or build relationships'”' (Murthy \& Dhiraj, 2013, p. 7).

There are many disadvantages that come from the use of the internet. According to Nielsen (2012), the internet users continue to spend more of their time to chat on social media sites than other types of webs. At the same time, the total time they spent for online through social media, both on PCs and mobile devices increased 99 percent to 121 billion minutes. For content contributors, the benefits of participating in social media have gone beyond just social sharing to build a reputation and bring career opportunities and monetary income, as discussed in Tang, Gu, \& Whinston (2012, pp. 41-75).

Kietzmann, Hermkens, McCarthy, \& Silvestre (2011, pp. 241-251.) present a framework for defining social media using seven functional building blocks: identity, conversation, sharing, presence, relationships, reputation, and groups.

a. Identity is a block that describes the extent to which users reveal their identity in a social media setting. This can include information such as name, age, gender, profession, location, and also involve information describing the user in a certain way.

b. Conversation is this block describes the extent to which users communicate with other users in a social media setting. Of course, many social media sites that are designed to facilitate a conversation between individuals and groups. This conversation occurred for various reasons, such as to meet and get acquainted with others, to establish a loving relationship, to build their self-esteem, or discuss trending topics. But sometimes other people take advantage of social media as a way to make their message heard and have the positive impact on the humanitarian, religious, environmental, economic, or political debate.

c. Sharing is a block that describes the extent to which users exchange, distribute and receive content. In many cases, however, sociality is about the objects that mediate the relationship between the reasons why they meet online and get along with each other.

d. The presence is the block describes the extent to which users can check whether other users can access. It includes the presence of other people, whether in the virtual world and /or in the real world, and whether they are available to be contacted.

e. The relationship is a block that describes the extent to which users can connect with other users in which two or more users have some form of association that brings them to communicate, share objects sociality, meet, or just simply list each other as friends or fans.

f. Reputation is a block that indicates the extent to which users can identify the presence of others as a matter of trust, including themselves, in a social media setting.

g. The group is a block illustrates the extent to which users can form communities and sub-communities are increasingly widespread, so he can have great friends, followers, and contacts.

Based on the definition above, the researcher concludes that computer mediated tools that allow people to create, share or exchange information, ideas, pictures, and videos in virtual communication and network by using seven 
functional building blocks: identity, conversations, sharing, presence, relationships, reputation, and groups.

\subsection{Writing Skill}

Writing means to create or reproduce the spoken message into written language. It involves an active process to organize, formulate and develop ideas on the paper so the readers can know and understand the author' message. In addition, the writing skill requires accuracy and proper grammar, spelling, punctuation, capitalization, and vocabulary (Bram, in Imeldi, 2001).

Khroma (1988, p. 172) explains that writing is the type of activities in which the author expresses the ideas in his mind into the paper word for word to become a sentence, sentence to paragraph and from paragraph to an essay. Similarly, Lindblom (1983) defines that writing is a way of learning to focus on minds to all the important things and learn about them. On the same statement, Ghaith (2002) explained that writing is a complete process which allows the author to explore thoughts and ideas and make them visible and concrete. There are four major types of writing, they are narrative, descriptive, expository, and persuasive. This article focused on descriptive writing.

In writing, the students will describe something that is tangible physical form or space that is important for their vision. In this case, they should organize sentences and details to explain the visual results in accordance with the depicted objects. The type of this organization is called the descriptive paragraph. In a descriptive paragraph, students must clearly describe the object through the written word. It is similar to what stated by Tompkins (1994, p. 73) who asserts that descriptive writing is to paint a picture with words. This means that the descriptive writing something like trying to visualize an object or person as clearly as possible. Troyka (1987, p. 96) explains that descriptive writing allows the author to share his sensual impression of a person, place or thing. The description gave the sensory impression of the feel, sound, taste, smell, and look of things.

The purpose of descriptive writing is to bring something out by words, such as an object, place, or in people character to the reader (Brown, 2001, p. 9). Therefore, the author must know well what he wants to explain. He should begin by observing the objects carefully to make significant details, bring a clear picture to the reader and avoid ambiguity. Troyka (1987, p. 23) states that by carefully capturing what the authors see, feel, and think about, and invite readers to share their experiences. Stanley (1988) stated that description text presents the appearance of things. The purpose of the description is to convey to the readers what something looks like and try to paint a picture with words.

Jacob et al. (in Bin Tahir, 2012, p. 79) point out five components in writing. They are content, organization, vocabulary, language use and mechanics.

a. Content is unity. This means that every sentence contributes to one principle, unifying thought. Furthermore, unity is the first quality of an effective sentence. When a sentence has a unity, it means that the sentence has a logical relationship (Lanon, 1995, p. 25).

b. Organization in writing involves coherence, order or importance, general to specific, specific to general, chronological order and spatial pattern.

c. Vocabulary as one of the requirements of good writing is always dependent on the effective use of the word. In the personal description, word plays a dual role: to communicate and to evoke the reader to understand and feel. This two-fold purpose is evident even in such a practical and common of writing as an advertisement. Effective use of words also associated with connotative or figurative language. They are all important nearly in all forms of writing, but particularly in personal descriptions.

d. Language use in writing involves the correct usage of grammar. There are many points of grammar, such as verb, noun, and agreement. Specific nouns and verbs give the reader a mental image of description. This particular noun can be characterized using the modifier of adjectives, adverbs and participles form. Briton (at Bin Tahir, 2012, p. 79) stated that there are many opportunities for making mistakes in using verbs and because we have the opportunity to recite and to correct what was written.

e. Mechanics includes the capitalization, punctuation, and spelling appropriately. This aspect is very important since it leads the reader to understand or recognize immediately what the author means certainty. The use of mechanical in writing will guide the reader easy to understand the conveying ideas or messages.

The five components of writing used to measure students' ability in writing descriptive without ignoring other components, as stated by O'Malley \& Pierce (1996) that the writing assessment should be evaluated not only the mechanical aspects of writing and grammar but also assess all components to determine some of the processes and the complexity involved in writing so teachers can evaluate which aspects are difficult experienced by students in the writing. To facilitate the assessment of writing components, the researchers used a scoring rubric 


\section{by Brown (2007).}

There were some previous researchers finding on the use of social media, ICT, and writing shown that those media will motivate and help the students to be successful in learning. As Solomon (2011, p. 222) conducted a research on SMS texting and its potential impacts on students' written communication skills. He found the SMS text messaging function could heighten the tendency among students to adopt non-standard uses and contracted forms of English words in their class work, examinations and research reports especially in an academic environment where English is the L2 of most students.

Lajuan \& Roger (2011, pp. 401-406) did a research entitled the use of social networking tool Twitter to improve college students' business writing skills. This study found that the students' writing skill can be improved by use of the social media tool, Twitter. Salomé Geertsema et al. (2011, pp. 475-487) conducted a research on title short message service (SMS) language and written language skills: educators' perspectives. The results indicated that the majority of educators viewed SMS language as having a negative influence on the written language skills of grade 8 and 9 learners. The influence was perceived as occurring in the learners' spelling, punctuation, and sentence length. A further finding was that the majority of educators address the negative influences of SMS language when encountered in written tasks.

Ru-Chu (2013, pp. 52-59) did a research on the effect of using facebook to assist English for business communication course instruction. The findings of this study indicate that incorporating Facebook in the English for Specific Purposes (ESP) course can effectively assist college students in learning business communication English. Bin Tahir \& Aminah (2014, pp. 235-241) did a research on improving students' writing skill through facebook at the University of Iqra Buru which found that learning writing through Facebook can improve the students' writing skill. Bin Tahir (2015a, pp. 174-181; 2015b, pp. 296-306) in his study on the use of voice chat in teaching speaking found the improvement of students' speaking skill and suggested for the further teachers and researchers to be more attention to the internet connection and the students' boredom or saturation when conducting English learning through Voice chat and Yahoo Messenger.

Based on previous findings, the researchers concluded that this research relates to all the previous studies especially in the aspects of ICT and the use of social media in language teaching and learning. The difference between this research and those researchers' study above is in the use of social media that is Facebook and Whatsapp in teaching writing. It is also different in the research method which starts with the quantitative approach to measuring the effectiveness of Facebook and Whatsapp application through experimentation and then through the qualitative approach to explore the factors influencing the students' achievement.

\section{Method}

This study employed pretest-posttest control group design, one randomly assigns subjects to the experimental and control groups and administers a pre-test on the dependent variable $Y$. The treatment is introduced only to the experimental subjects (unless two different treatments are being compared), after which the two groups are measured on the dependent variable. The researcher then compares the two groups' scores on the posttest. If there are no differences between the groups on the posttest, the researcher can then look at the average change between pretest and posttest $(Y 2-Y 1)$ scores for each group to determine if the treatment produced a greater change (gain) than the control situation (Donald et al., 2010, p. 307). This study was conducted from September 11, 2015, to March 16, 2016, at English Literature Department of Jember University, Indonesia.

\subsection{Participant (Subject) Characteristics}

The participant of the study for the experimentation was the third-semester students of English and Literature department in academic year 2015/2016. It had three classes with the number of the population were 93 students (Gay et al., 2006; Arikunto, 2006; Sugiyono, 2013). Since the number of population was large, the researchers used simple random sampling technique. Thus, one class was chosen as the experimental group which has been treated using Facebook and one class for the control group using WhatsApp. The number of sample for every group was 32 students. So, the total number of sample in this research was 64 students.

\subsection{The Instrument of the Research}

This research employed three instruments based on the research problem investigated; they were writing test, observation, and interview. The writing test involved some descriptive topics such as daily activity, occupation, organization, and environment to see the students' writing skill in terms of content, organization, vocabulary, language use and mechanics. Besides, the researchers also used the observation and interview used to obtain the qualitative data on factors affected the students' achievement. 


\subsection{Data Collection Procedures}

The data in this research will be collected through the following procedures:

\subsubsection{Pretest}

In the first meeting, the researchers conducted pre-test in order to know the students' writing skill and to find out their score. The pretest proceeded for 1 hours and 60 minutes as in the following steps: 1) The researchers distributed a picture and asked the students to write a descriptive text related to the picture, 2) The researchers evaluated the students' writing to find out more accurate data on their writing, and 3) The writing lecturer of English and Literature and directly assessed the students' writing skill.

\subsubsection{Treatment}

The treatments have been conducted in 6 meetings. Each meeting proceeded in 90 minutes divided into 40 minutes for theories and practicing by the peer, and 50 minutes for practicing via Facebook and WhatsApp. The procedures as follows: 1) The researchers introduced Facebook and WhatsApp to the students and how to sign in to the application group; 2) The researchers taught them how to sign into the application and explained the facilities of media, and 3) The researchers explained how to create and sign into the group chat. The procedures of giving treatments through the media using mixed categories as follows: 1) The researchers introduced the material that will learn by the students (together or alone); 2) The researchers explained the objectives of teaching and learning; 3) The researchers gave the motivation before the learning process in each meeting; 4) The researchers explaining each topic of learning; 5) The researchers distributed the writing material to the students; 6) Asked students to observe the picture and write the descriptive text; 7) The researchers gave the opportunities for students to ask the unclear topic and instruction, and 8) The researchers corrected the students' mistake in writing.

\subsubsection{Posttest}

After doing the treatments, the posttest given to the students which were supplied the same test in the pretest in order to find out the students' writing improvement. The procedures are: 1) Conducting the posttest after doing the treatment to find out the students' writing skill, 2) Evaluating the students' pretests and posttests, 3) The writing lecturer of English and Literature directly rated the students' scores, and 4) Analyzing the data by looking at the score on the pretest and posttest and then compared the results as a whole by using SPSS 18.0.

\subsubsection{Observation}

The observation type in this research was moderate participant where the researchers participated actively in some activities in collecting data. In this case, the researcher observed the ongoing process of learning. The data already collected from the observation aim at describing the students' learning process toward the use of social media in teaching writing.

\subsubsection{Interview}

The researchers interviewed the students and made tape recorded. Type of the interview was a semi-structured in which some questions were prepared before interviewing and some additional question asked on the spot. The interview was used to collect qualitative data or to confirm data on what had been observed, it was done at the end of the meeting. The way to interview was the group interview.

\subsection{Technique of Data Analysis}

In scoring the students' writing achievement in pretest and posttest, the researchers adopted the writing scoring rubric by Brown (2007) then converted the score based on the classification score at this university. In calculating the mean score and standard deviation of the students' writing skill (content, organization, vocabulary, language use and mechanics), the researchers used SPSS program version 18.0. The observation and interview data of the study analyzed descriptively using the flow by Miles \& Huberman (1994) who suggested the three concurrent flows of action; a) data reduction; b) data display; and c) conclusion drawing/verification.

The hypotheses were tested by using inferential analysis. In this case, the researchers used t-test (testing of significance) or paired samples test for independent sample test that a test to know the significance of the difference between the results of students' mean scores in pretest and posttest. The level of significance in this research is $(\alpha)=0.05$ with the degree of freedom $(\mathrm{df})=64$, where $\mathrm{N}-2=62$ is 2.000 . This means that if the result of computed SPSS 18 found that the t-test is less or same as 2.000, $\mathrm{H}_{0}$ (Null Hypothesis) is accepted. In contrast, if the result of t-test is more than $2.000, \mathrm{H}_{0}$ is rejected. 


\section{Results}

Based on the quantitative and qualitative data which gained from experimentation between experimental (using Facebook) and control group (using WhatsApp, and also the data from observation and interview can be described as follows:

\subsection{Improvement of Students' Writing Skill via the Social Media}

The data on the frequency and percentage of the students' writing skill through the social media in pre-test can be seen in the following tables.

Table 3. The frequency and percentage of the students' writing skill in pretest

\begin{tabular}{llllll}
\hline Classification & Range of score & \multicolumn{2}{l}{ Experimental Group } & \multicolumn{2}{l}{ Control Group } \\
\hline Excellent & & $\mathrm{F}$ & $\%$ & $\mathrm{~F}$ & $\%$ \\
Very good & $96-100$ & 0 & 0 & 0 & 0 \\
Good & $86-95$ & 0 & 0 & 0 & 0 \\
Fairly good & $76-85$ & 7 & 21.9 & 4 & 12.5 \\
Fair & $66-75$ & 4 & 12.5 & 5 & 15.6 \\
Poor & $56-65$ & 13 & 40.6 & 14 & 43.8 \\
Very poor & $36-55$ & 8 & 25.0 & 9 & 28.1 \\
\hline Total & $00-35$ & 0 & 0 & 0 & 0 \\
\hline
\end{tabular}

Table 3 shows that most of the students' writing skill in both experimental and control group were categorized as fair at the beginning where 8 students $(25.0 \%)$ in experimental and 9 students $(28.1 \%)$ in control group were in the poor category and no one of both groups was in the very poor category. 13 student (40.6\%) in experimental and 14 students $(43.8 \%)$ in control group were in fair category, 4 students (12.5\%) in experimental group and 5 students $(15.6 \%)$ in fairly good category, 7 students $(21.9 \%)$ in experimental and 4 students $(12.5 \%)$ in control group were in good category. The result on the table shows that most of the students have the same level of writing skill as fair or average before applying the social media for both experimental and control group. While after treatment, the posttest score for the experimental and control groups can be seen in the table below:

Table 4. The frequency and percentage of the students' writing skill in posttest

\begin{tabular}{llllll}
\hline Classification & Range of score & \multicolumn{2}{l}{ Experimental Group } & \multicolumn{2}{l}{ Control Group } \\
\hline Excellent & & F & $\%$ & F & $\%$ \\
Very good & $96-100$ & 0 & 0 & 0 & 0 \\
Good & $86-95$ & 3 & 9.3 & 4 & 12.5 \\
Fairly good & $76-85$ & 9 & 28.1 & 6 & 18.7 \\
Fair & $66-75$ & 12 & 37.5 & 10 & 31.2 \\
Poor & $56-65$ & 6 & 18.7 & 9 & 28.1 \\
Very poor & $36-55$ & 2 & 6.2 & 3 & 9.3 \\
\hline Total & $00-35$ & 0 & 0 & 0 & 0 \\
\hline
\end{tabular}

The table shows that the students' achievement in the experimental and control group has improved. In the experimental group, the score of the students tends to spread from fairly good to very good category. There were 3 students $(9.3 \%)$ in the very good category, 9 students $(28.1 \%)$ were in good, 12 students $(37.5 \%)$ in the fairly good category, 6 students (18.7\%) in fair category, and there were still 2 students $(6.2 \%)$ in the poor category. Unlike for the control group, the students' scores also were spread dominantly in fairly good to very good category and no one of the student was categorized as excellent. There were 4 students $(12.5 \%)$ categorized as very good, 6 students (18.7\%) categorized as good, 10 students (31.2\%) categorized as fairly good, 9 students (28.1\%) in fair category, and 3 students $(9.3 \%)$ categorized as poor. The mean score of both groups can be seen in the table below: 
Table 5. The mean score and standard deviation of the students' writing in pretest and posttest

\begin{tabular}{lllllllll}
\hline \multirow{2}{*}{$\begin{array}{l}\text { Writing } \\
\text { Component }\end{array}$} & \multicolumn{3}{l}{ Experimental Group } & \multicolumn{5}{c}{ Control Group } \\
\cline { 2 - 9 } & Pretest & \multicolumn{3}{c}{ Posttest } & Pretest & Posttest \\
\cline { 2 - 9 } & Mean & Std. & Mean & Std. & Mean & Std. & Mean & Std. \\
& Score & Deviation & Score & Deviation & Score & Deviation & Score & Deviation \\
\hline Content & 63.13 & 10.90 & 79.69 & 7.39 & 61.35 & 9.75 & 78.56 & 9.70 \\
Organization & 62.91 & 8.02 & 76.31 & 8.40 & 63.13 & 10.90 & 77.23 & 9.06 \\
Vocabulary & 30.63 & 10.14 & 45.66 & 8.59 & 29.06 & 8.56 & 42.81 & 16.11 \\
Language use & 42.50 & 15.30 & 60.13 & 11.23 & 40.63 & 16.02 & 59.25 & 9.75 \\
Mechanics & 46.20 & 8.25 & 62.91 & 8.02 & 46.66 & 8.59 & 66.25 & 9.75 \\
\hline
\end{tabular}

Table 5 indicates that there were the difference score and standard deviation in students' writing descriptive achievement. The distribution score for experimental and control group in posttest shows the difference from the pretest. The data shows the lack of students' vocabulary $(30.63<45.66)$, language use $(42.50<60.13)$, and mechanics $(46.20<62.91)$ in experimental group and also vocabulary $(29.06<42.81)$, language use $(40.63<$ $59.25)$, and mechanics $(46.66<66.25)$ in control group pretest score. It indicated the improvement of each component of writing skill in posttest was 10 to $20 \%$ after the treatment. Although there was increasing of students' writing score in posttest but the main score did not show the significant improvement of their writing skill. So the researchers then look at the average change between pretest and posttest $(Y 2-Y 1)$ scores for each group to determine if the treatment produced a greater change (gain) than the control situation. Below is the T-Test result as whole as pretest and posttest of students' writing skill:

Table 6 . The probability value of t-test of the students' achievement in pretest and posttest

\begin{tabular}{llll}
\hline & $\mathrm{T}$ & 2 Tailed Value & \\
\hline Control Pretests and Experimental Pretest & 1.000 & 1.00 & There was No Different \\
Control Posttest and Experimental Posttest & 2.673 & 0.04 & Different \\
\hline
\end{tabular}

The result of data analysis as summarized in table 6 on pretest and posttest of control and experimental group, the researchers found that the probability value (1.00) is higher than the level of significance at t-table $(0.05)$ and the degree of freedom 62 . The data also showed that the t-count value was smaller than t-table $(1.000<2.000)$. It indicated that the alternative hypothesis $\left(\mathrm{H}_{1}\right)$ was rejected and the null hypothesis $\left(\mathrm{H}_{0}\right)$ was accepted. In the other word, there was no significant difference between the students writing skill in the pre-test. After treatment, the researchers found that the probability value $(0.04)$ was smallest than the level of significance at t-table $(0.05)$ and the degree of freedom 62. It indicated that the alternative hypothesis $\left(\mathrm{H}_{1}\right)$ was accepted and the null hypothesis $\left(\mathrm{H}_{0}\right)$ was rejected. In the other word, there was difference score between the students writing skill in pretest and posttest but not significant. Therefore, the researchers continued to study the case in the qualitative approach to explore the factors affecting students' score achievement via observation and interview, and the results can be described as follows.

\subsection{Factors Affecting the Students' Achievement}

Based on the observation and interview, the researchers found the two main factors affected the students' writing achievement; they are the factors related to the students' ability and the factors connected to the social media application.

The students have low ability in mastering vocabulary, language use, and mechanics which hindered them to write their idea. It could be seen from many mistakes occurred in their writing. In vocabulary, there were many ineffective choices of words and word forms, confusing words, and misuse of vocabularies. There were also inaccuracies of grammatical or agreement and some errors of spelling, punctuation, and capitalization. Those errors occurred due to differences in the writing of English word with its pronunciation, so they were difficult to remember the way of word writing. In other words, they wrote the word based on its pronunciation. It is in line to what informed by students (NA, RR, YS, and PIK):

"English is a strange language which has different ways of writing and pronunciation so it is difficult for us to write the words correctly, especially in unfamiliar words"

The related to the social media such Facebook and WhatsApp were the outdated application or no longer relevant to the students' need in learning. It is due to the absence of tools modification that interest students to 
learn so that the media is losing its function as tools of learning and they just used it as a medium of gossip or spreading the hoax. It is in line with the students' statement via the interview (HR, BJT, IPS, and YR):

"We felt boredom of using the Facebook or WhatsApp because there is nothing new in those applications and low of internet connection, so we just use them at once in a while for gossip or spreading the hearsay".

The rapid development of technological also has spoiled the students to choose things that are instant to use, although it includes cheating. It can be seen from the results of the students' writing which show clearly that they used the google translator to translate their L1 into English, as can be seen in the student's work below:

The image seen two small children playing ball in the side of the house while waiting for mango fall, yet did not dare because mrk pack petany were guarding the house and cleaning the yard, they were exhausted to play and wait, eventually they return to their homes.

Source: Research Data on Students’'Workshet, 2016.

The paragraphs contained in the box above shows that the students used the google translator in writing a descriptive text then they paste them into the Facebook or WhatsApp group. From these findings, the researchers concluded that the factors affected the students' achievement in writing were the absence of modifications to the application on Facebook and WhatsApp so that the students feel bored to use them, they occasionally used them as a medium of gossip and hearsay, and they also preferred to exploited the instant and practical things like the google translator in cheating.

\section{Discussion}

Based on the findings of quantitative data indicated that the use of social media, such as Facebook or WhatsApp can improve students' achievement in writing descriptive text, but the increase was not significant because there were 5 students $(15.5 \%)$ still in a category poor, only 7 students $(21.8 \%)$ were categorized as very good and no student was categorized Excellent. Besides, the students have low achievement in three of the component such vocabulary, language use, and mechanics. Mastering these elements was crucial in writing which allows the students to explore thoughts and ideas and make them visible and concrete (Ghaith, 2002; Troyka, 1987, p. 96).

The findings also found several factors that cause of not significant of increase in learning outcomes, such as the absence of modifications to the applications on Facebook and WhatsApp so that the students feel bored to use them, they occasionally used them as a medium of gossip and Hearsay, Also they preferred to and exploited the instant or practical things like the google translator in cheating the answer. These findings indicated that the use of social media in teaching is not always successful, so that a teacher who applied the social media in teaching required being creative, varied, and modify instructional medium so that it can be fun for students to learn. It is in line with Campbell \& Dickinson (1996, p. 17) state that teachers need to incorporate a variety of strategies so that they reach and successful with more students than they have been in the past. It means that teachers should apply various techniques or teaching and learning styles and media to cover the intelligence that occurs in the class. Long Van Nguyen (2010) also suggested that the advantages, of course, created an enjoyable, entertaining social learning which gives pleasure to the students. Those benefits made the students more interested in joining the writing class and automatically influenced their performance.

In conducting research or teaching and learning process through the social media, Bin Tahir (2015, pp. 175-181) recommended for teachers and next researchers to take into account many aspects of online learning such internet connection, the novelty of the media, and students' saturation with more elaborate preparation, more careful monitoring of the places and facilities of computer, timely adjusting of the project, and cost, so greater achievement arising from the social media that would be more promising for language teachers and learners.

The low of internet connection will affect the mood of the students in learning which will cause their anxiety while waiting for access to the page and bored in browsing. It is in line to Bin Tahir (2015, pp. 296-306) stated that the most failure of conducting online learning was the internet connection. Besides, the teacher should pay full attention to the students' awareness in utilizing the technology.

Based on the findings and the theories, the researchers can interpret that the social media tools which are static and do not update to the needy should always be considered by teachers before applying it, if it is not addressed properly, then the learning process would be boring for students, so it takes teachers' creativity and innovative in designing learning material or media. 


\section{Conclusion}

Based on the results, the researchers found that;

a. The use of social media such Facebook and WhatsApp did not significantly improve the students' writing skill.

b. The factors affecting insignificance of students' achievement in learning writing descriptive text including the low of language use, vocabulary and mechanics; non-updated application of social media with varying facilities; the low of internet connection; switching of the social media function; the students' saturation and boredom, and the tendency of students to use things that are instant like google translator.

Based on the conclusion above, the researchers offer some suggestions for the university, lecturers, and further researchers as follows:

a. The university should set the standard input and output of students who wish to study at the language faculty and facilitate adequate internet connection on the campus that will help the lecturers and students to conduct e-learning via the web or the social media.

b. The lecturer must focus on enriching the students' vocabulary mastery and grammar, be creative and innovative to modify the social media facilities which will avoid of students' saturation and boredom. Besides, a lecturer who conducts teaching and learning via the social media must build the students' awareness and makes a strict control in the learning process to avoid from cheating.

c. For the next researchers and the practitioners to consider the students' mastery of English before applying teaching and learning and to prefer the novelty of the social media facilities which helpful in motivating the students and increase their score achievement in learning.

\section{References}

Aichner, T., \& Jacob, F. (2015). Measuring the Degree of Corporate Social Media Use. International Journal of Market Research, 57(2), 257-275.

Almeida d'Eça, T. (2002). To chat or not to chat in the EFL classroom, that is the question! Paper presented at the Language-Communication-Culture. International Conference, University of Évora, Portugal. Retrieved from http://www.malhatlantica.pt/teresadeca/papers/evora2002/chat-and-efl.htm

APJII. (2015). Internet Penetration in Indonesia: Rising but Slower than Wanted. Retrieved from $\mathrm{http}: / / \mathrm{www}$.indonesia-investments.com/tag/item31?tag=1292

Arikunto, S. (2006). Prosedur Penelitian. Suatu Pendekatan Praktik. Jakarta: Rineka Cipta.

Bin Tahir, S. Z. (2012). Redefining Terms of Teaching and Learning Strategy, Method, Approach, Technique, and Model. Public lecture of Microteaching at English Education Department of University of Iqra Buru, November 01st 2012. Retrieved from https://scholar.google.com/citations?view

Bin Tahir, S. Z. (2012). Teaching English as World Language: Pengajaran Bahasa Inggris. Jakarta: Pustaka Qalam.

Bin Tahir, S. Z. (2015a). Improving Students' Speaking Skill through Yahoo Messenger at University of Iqra Buru. International Journal of Language and Linguistics, 3(3), 174-181. https://doi.org/10.11648/j.ijl1.20150303.20

Bin Tahir, S. Z. (2015b). Improving Students' Speaking Skill through Voice Chat at University of Iqra Buru. $\begin{array}{llll}\text { Journal of Modern Education 296-306. } & \text { Review, }\end{array}$ https://doi.org/10.15341/jmer(2155-7993)/03.05.2015/009

Bin Tahir, S. Z., \& Aminah, A. (2014). Improving Students' Writing Skill through Facebook at University of Iqra Buru. Proceeding of ICT for Language Learning (7th ed., pp. 235-241).

Brown, H. D. (2007). Teaching by Principles: An Interactive Approach to Language Pedagogy (2nd ed.). New York: Longman.

Cambell \& Dickison. (1996). Teaching and Learning through Multiple Intelligences. Boston: Ellyn \& Bacon.

Cohen, L., Lawrence, M., \& Keith, M. (2007). Research Methods in Education (6th ed.). New York: Routledge.

Donald, A. et al. (2010). Introduction to Research in Education (8th ed.). Belmont: Wadsworth Cengange Learning.

Gay, L. R., Mills, G., \& Airasian, P. (2006). Educational Research; Competencies for Analysis and Applications 
(8th ed.). New Jersey: Pearson Prentice Hall.

Ghaith, G. (2002). The Nature of Writing Process, Approaches, Model, and Process Wrinting Activities. Retrieved from http:/ghaith.tsx.org

Imeldi, M. (2001). Facilitating the First Semester of English Department Students in Writing Activity. Unpublished thesis. FBS UNM Makassar.

Internet live stats, International Telecommunication Union (ITU), World Bank, and United Nations Population Division. (2015). Indonesia internet users. Retrieved from http://www.internetlivestats.com/internet-users/indonesia

Kaplan, A. M., \& Haenlein, M. (2010). Users of the world, unite! The challenges and opportunities of social media. Business Horizons, 53(1), 61. https://doi.org/10.1016/j.bushor.2009.09.003

Kietzmann, J., \& Kristopher, H. (2011). Social media? Get serious! Understanding the functional building blocks of social media. Business Horizons, 54, 241-251. https://doi.org/10.1016/j.bushor.2011.01.005

Kroma, S. (1988). Action Research in Teaching Composition. London: Longman

Lajuan, D., \& Yin, L. R. (2011). The Use of Social Networking Tool Twitter to Improve College Students' Business Writing Skills. Issues in Information System, 12(1), 401-406.

Lanon, J. M. (1992). Writing Process. New York: Harper Collins.

Lindblom, P. (1983). The Elements of Writing. New York: Maxwell Maemillan.

Long, V. N. (2010). Computer Mediated Collaborative Learning within a Communicative Language Teaching Approach: A Sociocultural Perspective. The Asian EFL Journal, 12(1).

Miles, M. B., \& Huberman, A. M. (1994). Qualitative Data Analysis: An Expanded Sourcebook. London: Sage.

Millward et al. (2015). The Use of Social Network Sites as an E-Recruitment Tool. Journal of Transnational Management, 20(1), 31-49. http://dx.doi.org/10.1080/15475778.2015.998141.

Millward, S., Lee, M. A., \& Bischoff, P. (2015). The latest numbers on web, mobile, and social media in Indonesia (INFOGRAPHIC), Thompson Rivers University. Retrieved from https://www.techinasia.com/indonesia-web-mobile-data-start-2015/

Murthy, D. (2013). Twitter: Social Communication in the Twitter Age (pp. 7-8). Cambridge: Polity.

Nana, Y. A. (2012). A Research Analysis of Online Social Networking Sites (SNSs) and Social Behaviour at University of Ghana (UG), Legon, Accra, Ghana. International Journal of Science and Technology, 2(7), 462-472.

Nation, I. S. P., \& Macalister, J. (2010). Language curriculum design. New York: Routledge, Taylor \& Francis Publisher.

Nielsen. (2012). State of the media: The social media report 2012. Featured Insights, Global, Media + Entertainment.

O’Malley, J. M., \& Pierce, L. V. (1996). Authentic Assessment for English Language Learners: Practical Approaches for Teachers. Massachusetts: Addison Wesley Publishing Company.

Pavlik, MacIntoch, John, \& Shawn. (2015). Converging Media (4th ed., p. 189). New York, NY: Oxford University Press.

Salija, K. (2004). The Effects of Using Formal Outlines Ini Writing Exposition. Unpublished disertation. Malang: State University of Malang Press.

Salomé, G., Charene, H., \& Chantelle, V. D. (2011). Short message service (SMS) language and written language skills: educators' perspectives. South African Journal of Education, 31, 475-487. https://doi.org/10.15700/saje.v31n4a370

Shih, R. C. (2013). Effect of Using Facebook to Assist English for Business Communication Course Instruction. TOJET: The Turkish Online Journal of Educational Technology, 12(1), 52-59.

Solomon, A. D. (2011). SMS Texting and Its Potential Impacts on Students' Written Communication Skills. International Journal of English Linguistics, 1(2), 222.

Sugiyono. (2013). Metode Penelitian Kombinasi (Mixed Method). Bandung: Penerbit Alfabeta.

Tang, Q., Gu, B., \& Whinston, A. B. (2012). Content Contribution for Revenue Sharing and Reputation in Social 
Media: A Dynamic Structural Model. Journal of Management Information Systems, 29, 41-75. https://doi.org/10.2753/MIS0742-1222290203

The Jakarta Pos. (2015). Internet users in Indonesia reach 73 million. Retrieved from http://www.thejakartapost.com/news/2015/03/10/internet-users-indonesia-reach-73-million.html\#sthash.Y8 xE6Zfy.dpuf

Tompkins. (1991). Language Arts: Content and Teaching Strategies. New York: Macmillan.

Troyka, L. O. (1987). Simon and Schuster. Hand Book for Wirters. London: Prentice Hall.

\section{Copyrights}

Copyright for this article is retained by the author(s), with first publication rights granted to the journal.

This is an open-access article distributed under the terms and conditions of the Creative Commons Attribution license (http://creativecommons.org/licenses/by/4.0/). 